\title{
Comparative Analysis of Financial Performance Before and After Acquisition
}

\author{
(A Study in Acquiring Company Listed in Indonesian Stock \\ Exchange, Period of 2012-2018)
}

Ilham Yunus ${ }^{1 *}$, La Ode Rasuli ${ }^{2}$ Amir Lukum ${ }^{3}$

\author{
$1,2,3$ Gorontalo State University \\ * Corresponding author. Email: Ilhamyunus570@gmail.com.
}

\begin{abstract}
The present study delves to analyze the difference of company financial performance prior to and after acquisition in companies listed in the Indonesian Stock Exchange. The financial performance is measured by involving seven financial ratios: current ratio (CR), total asset turnover ratio (TATO), debt to equity ratio (DER), net profit margin (NPM), return on assets (ROA), return on equity (ROE), and earning per share (EPS). The comparative quantitative study involved the population of seven companies listed in the Indonesian Stock Exchange that conducted acquisition activity during the period of 2012-2018. From the population, five companies were acquired as the samples by purposive sampling technique. The study employed normality data test and Wilcoxon signed rank test as the data analysis techniques. The results showed that four financial ratios, i.e., current ratio (CR), debt to equity ratio (DER), net profit margin (NPM), and earning per share (EPS) are not significantly different prior to and after the acquisition. On the other hand, the ratios of total asset turnover ratio (TATO), return on assets (ROA) dan return on equity (ROE) yield negative significant result before and after acquisition. Therefore, the paper concludes that acquisition impacts negatively to the company financial performance.
\end{abstract}

Keywords: Financial Performance, Acquisition, Financial Ratio

\section{INTRODUCTION}

In this modern time, companies are required to take action based on the market demands for the sake of the company's performance sustainability. Every company primarily tries to improve its performance, which resulted in the emergence of competition between companies. Each company will always avoid an environment of unfair competition and tend to clash against each other. Such environment will unknowingly harm the companies around it. One of the company strategies that can be done in order to compete with other companies is by expanding [1].

An expansion is divided into two parts, namely internal expansion and external expansion. Internal expansion is executed without the contribution of the company's external organization, such as using new sales methods and increasing production capacity, while external expansion is developed through business combinations, such as mergers and acquisitions. [2].

Based on the previous statement, one of the expansions that can be carried out by the company is by making acquisitions. Acquisition is the transfer of control over a company that is taken over (acquiree) as a result of a form of takeover of company ownership by the acquirer [3].

Mergers and acquisitions are believed to provide benefits for companies, including augumenting capabilities in marketing, research, managerial skills, technology transfer, and efficiency in the form of reducing production costs. Acquisition is expected to 
bring positive changes to the company's financial performance [4].

Based on data from the Commission for the Supervision of Business Competition (KPPU), in the last 5 years from 2014-2018, acquisition activities have always been volatile and generally have increased, which can be seen in the table below:

Table 1. Companies Conducting Mergers and Acquisitions

\begin{tabular}{cccc}
\hline Year & Merger & Acquisition & Total \\
\hline 2014 & 2 & 53 & 55 \\
2015 & 3 & 48 & 51 \\
2016 & 1 & 64 & 65 \\
2017 & 2 & 88 & 90 \\
2018 & - & 74 & 74 \\
\hline
\end{tabular}

Source: [20]

The table shows the high number of acquisition activities that occur in annual basis. The main objective of a business merger is to attain various synergies, including economic synergy, technology synergy, and managerial synergy [5]. Seeing the phenomenon of increasing acquisition activity, it turns out that there are still many current research results which state that there is not any significant and positive change in terms of the company's financial performance after making an acquisition. In fact, the company experienced negative changes

The success or failure of a company's acquisition can be seen from the results of the company's postacquisition financial performance. The financial performance is a reflection of company's financial health condition in a certain period [3], which also can be said as a measure of company achievement results. Financial performance is defined as management achievement, in this case, a financial management in achieving company goals, namely generating profits and increasing company value [Naziah, et al., 2014].

Several similar studies have been conducted prior to this research show that there is no effect of acquisition on the company's financial performance. The results of [7] show that mergers and acquisitions possess a negative and significant effect on debt to equity ratio and return on assets, but also have no effect on the current ratio. There is a significant negative effect of the debt to equity ratio on return on assets. Current ratio has no effect on return on assets.

Another research conducted by [5] shows that there is no significant difference in current ratio, fixedasset turnover, total asset turnover, debt to total assets ratio, net profit margin and asset return after mergers and acquisitions. Unlike the case with previous studies, the research conducted by [6] shows that in general, there are differences in the performance of the company results before and after mergers and acquisitions, because the performance of companies resulting from mergers and acquisitions has increased significantly.

Based on the previous statements, it can be concluded that there are differences among the results of previous studies which are considered inconsistent and there was a mismatch between the theory and the conditions in the field. There is a difference in this research with previous studies where the number of samples, company names, and years of research are different.

Based on the description above, it motivated the researcher to conduct a research and re-test regarding "Comparative Analysis of Financial Performance Before and After Acquisitions in Companies Listing on the Indonesia Stock Exchange (BEI)".

\section{LITERATURE REVIEW}

\subsection{Signal Theory}

Signal theory is based on the assumption that the information received by each party is not the same or simply put, signal theory is concerned with information asymmetry. It shows the existence of information asymmetry between company management and the parties with an interest in the information. As a result, managers are needed to provide the information required by interested parties through the publication of financial reports [8].

Signal theory explains a sign given by management to parties who possess an interest in the company about how management perceives the company's prospects in the future [9]. This signal is in the form of information about what management has done to realize the owner's wishes. 


\subsection{Financial Performance}

Financial performance is a reflection of the financial health condition of the company in a certain period, which can be also said as the measure of company achievement results [3]. Financial performance is defined as management achievement, in this case, financial management in achieving company goals, namely generating profits and increasing firm value [6]. In this research, the financial performance analysis aims to assess the implementation of the company's strategy in terms of acquisitions.

\subsection{Financial Ratio}

An analysis of financial performance with financial ratios is important to determine the strengths and weaknesses of a company. This information is needed to evaluate the performance accomplished by the company's management in the past and also for contemplation in preparing future company plans. One of the ways to obtain useful information from the company's financial statements is to perform financial ratio analysis [10].

Financial ratio analysis is a company performance analysis instrument that explains various relationships and financial indicators aimed at showing changes in financial conditions or past operating performance and helps to illustrate the trend of these changes, which also shows the risks and opportunities inherent in the company concerned. [11].

\subsection{Types of Financial Ratio}

Some of the ratios used to measure the company's financial performance are as follows:

\subsubsection{Liquidity Ratio}

Liquidity ratio is the ability of a company to meet its short-term obligations in a timely manner [11]. The liquidity ratio in this research is proxied by the Current Ratio $(C R)$.

Current Ratio (CR) is a ratio that compares the current assets owned by a company with short-term debt. Current assets include cash, accounts receivable, securities, inventories and other current assets. Meanwhile, short-term debt includes accounts payable, notes payable, bank loans, salaries payable, and other payables that must be paid immediately [12].

$$
\text { Formula: } \mathrm{CR}=\frac{\text { Current Assets }}{\text { Current Liabilites }}
$$

\subsubsection{Activity Ratio}

The activity ratio is used to measure the extent to which the company uses its resources to support the company's activities. The greater the activity ratio, the better the company's performance in managing its assets [1]. The activity ratio in this research is proxied by Total Asset Turnover (TATO).

Total Assets Turnover Ratio (TATO) is a measure of the effectiveness of asset utilization in generating sales. A great asset turnover will result an effective company asset management [12].

$$
\text { Formula: TATO }=\frac{\text { Sales }}{\text { Total Asset }}
$$

\subsubsection{Solvency Ratio}

This ratio illustrates the relationship between corporate debt to capital and assets. This ratio can see how far the company is financed by debt or external parties with the company's ability as described by capital [6]. The activity ratio in this research is proxied by the Debt to Equity Ratio (DER).

Debt to Equity Ratio (DER) is a ratio that describes the extent to which owner's capital can cover debts to outsiders [14].

$$
\text { Formula: DER }=\frac{\text { Total Debt }}{\text { Total Equity }}
$$

\subsubsection{Profitability Ratio}

The profitability ratio is a ratio to measure the effectiveness of management as a whole, which is indicated by the size of the level of profits obtained in relation to sales and investment. The better the profitability ratio describes the high profitability of a company [16]. The profitability ratio in this research is proxied by Net Profit Margin (NPM), Return on Assets (ROA) and Return on Equity (ROE).

- Net Profit Margin (NPM) calculates the range of company's ability in generating net income at a certain sales level. This ratio is also interpreted as 
the company's ability to reduce costs (a measure of efficiency) in the company in a certain period [15].

$$
\text { Formula: NPM }=\frac{\text { Profit }}{\text { Sales }}
$$

- Return on Asset (ROA) shows the amount of net profit that the company accrues when measured from the value of assets [15].

$$
\text { Formula: ROA }=\frac{\text { Earning After Taxes }}{\text { Total Asset }}
$$

- Return on Equity (ROE) is used to measure the company's ability to generate net income based on certain capital [15].

$$
\text { Formula: ROE }=\frac{\text { Net Income }}{\text { Total Equity }}
$$

\subsubsection{Market Ratio}

Market ratio is a ratio that describes the conditions that occur in the market. This ratio is able to provide an understanding for the management of the company on the conditions of implementation that will be implemented and its impact in the future [11]. The market ratio in this research is proxied by Earnings per Share (EPS).

Earnings per Share (EPS) is a measure of a company's ability to generate profits per share of the owner [12].

$$
\text { Formula: EPS }=\frac{\text { Net Profit }}{\text { Number of Equity Shares }}
$$

\subsection{Acquisition}

Acquisition is an English word that refers to the act of purchasing or obtaining an object to be added into the inventory of objects one has possessed. In business terminology, acquisition is interpreted as the takeover of ownership or control of stock/assets of a company by another company, in a context where the company that takes over and the company whose assets being taken over are two separate legal entity [17].

In a legal context, as referred to in the Law No. 40/2007 concerning Limited Company, acquisition is the legal act committed by a legal entity or individual to take over a company share that results in the transfer of control of the share. To be considered as a share acquisition/take over, an acquisition must take over at least $51 \%$ of all company shares of the target company [18].

\section{6 Research Hypothesis}

Mergers and acquisitions are considered to provide advantages for the company including increased skills in marketing, research, managerial skills, technology transfer, and efficiency in the form of decreased production costs [4]. The main purpose of merging companies is the acquisition of various synergies, such as economic, technology, and managerial synergy. Therefore, the acquisition is expected to provide a good impact for the company's financial performance [5].

\subsubsection{The Pre and Post Acquisition difference in Current Ratio}

The success of mergers and acquisitions can be seen from the increase in the financial performance of the company. After the company's mergers and acquisitions, the firm will increase in size by the accretion of assets, responsibilites and equities of the company [9]. Based on these considerations, the hypothesis proposed in this study is as follows:

H1. There is a significant difference in Current Ratio $(C R)$ between the company's financial performance before the acquisition and after the acquisition.

\subsubsection{The Pre and Post Acquisition Difference of the Total Asset Turnover Ratio}

The greater the Total Asset Turnover, the quicker the assets can turn around and make profit that shows the more efficient use of overall assets in generating sales. The acquisition causes the assets of the company to be combined, the joining managements is also expected to more be effective and efficient, in which the company's ability to manage its assets should be better [1]. Based on these considerations, the hypothesis proposed in this study is as follows:

$\mathrm{H} 2$. There are significant differences in the Total Asset Turnover Ratio (TATO) between the company's financial performance before the acquisition and after the acquisition. 


\subsubsection{The difference in Debt To Equity Ratio Before and After Acquisition}

The greater the capital owned, the smaller the amount of loan capital used to finance the company's assets. The company merging is expected to minimize the use of debt by the company. The smaller the debt owned by the company, the more confident and interested the investor will be in investing [1]. Based on these considerations, the hypothesis proposed in this study is as follows:

H3. There are significant differences in Debt to Equity Ratio (DER) between the company's financial performance before and after the acquisition.

\subsubsection{The Pre and Postthe Acquisition difference of Net Profit Margin}

The greater the NPM, the more productive the company performance will be, which will increase the confidence of the investors to invest. Based on these explanations, the acquisitioning company will expect to achieve synergies that will further facilitate in increasing the profit of the company [1]. Based on these considerations, the hypothesis proposed in this study is as follows:

H4. There are significant differences in the Net Profit Margin (NPM) between the company's financial performance before the acquisition and after the acquisition.

\subsubsection{The Pre and Post Acquisition difference of Return On Assets}

The reason companies do acquisitions is to achieve economical operation. Performing acquisition activities can increase the amount of assets owned by a company [10]. Greater company's assets are able to increase profits for the company. Based on these objectives, then the appropriate ratio to be used in this measurement is Return on Assets. Return on Assets (ROA) shows how much net profit obtained by the company when measured from the value of the assets [14]. Based on these considerations, the hypothesis proposed in this study is as follows:

H5. There are significant differences in Return on Assets (ROA) of the company before and after acquisition.

\subsubsection{The Pre and Post Acquisition difference of Return on Equity}

Return on Equity shows the extent of the company's assets abilities in generating operating profit, as well as to measure the level of profit from the investment that has been made by owners of their own capital or shareholders of the company. Merging and acquisitioning companies surely will expect to achieve synergy, both in terms of company economy or management that will further facilitate the increase of company profit indicated by the numbers on the high ratio of Return on Equity [4]. Based on these considerations, the hypothesis proposed in this study is as follows:

H6. There are significant differences in the Return on Equity (ROE) between the company's financial performance before the acquisition and after the acquisition.

\subsubsection{The Pre and Post Acquisition Difference of the Total Asset Turnover Ratio}

Achieving economical operation are the objectives of the company to do acquisition. Acquisitions can support the operations of the company by increasing the profit obtained by the company, which will also increase the company's value. Based on these objectives, the appropriate ratio to be used in this measurement is the Earnings per Share [10]. Based on these considerations, the hypothesis proposed in this study is as follows:

H7. There is a significant difference in Earning per Share (EPS) between the company's financial performance before and after the acquisition.

\section{RESEARCH METHOD}

The method used in this research was quantitative comparative which applies secondary data analysis. The secondary data used in this research were obtained from the financial statements of a company that conducted acquisition in 2015 which was listed in Indonesia stock Exchange before or since 2012, obtained from www.idx.co.id and www.idnfinancials.com. Secondary data were employed because those were easily obtained from a reliable source. 
The populations in this research were seven go public companies that conducted acquisition activities in 2015. The sampling techniques used in this research were non-probability and purposive sampling approach with previously established criteria, in which there were 5 companies used as samples.

Empirically, this research analyzed the measurement of the company's financial performance both three years before and after the acquisition. Financial ratios were employed as the variable to measure the financial performance of the company in this research. There are seven financial ratios used in this study, they are Current Ratio (CR), Total Assets Turnover Ratio (TATO), Debt to Equity Ratio (DER), Net Profit Margin (NPM), Return on Assets (ROA), Return on Equity (ROE), Earnings Per Share (EPS).

Data analysis used in this research were descriptive statistical analysis and pre-requirement test of data analysis (Normality test). A descriptive-statistical analysis was employed to analyze and present the quantitative data to yield an elaboration of the companies treated as research sample. The analysis technique describes the data as observed from the maximum value, minimum value, mean, deviation standard, and variance [4].

Data normality test was conducted to identify whether or not the data are normally distributed. The test is also significant to identify the most proper statistical test to employ in hypothesis testing. A parametric test will be employed if the data are normally distributed; if the data are abnormally distributed, the non-parametric statistical test is involved. Moreover, the normality test employed Kolmogorov-Smirnov test with criteria as follows: the data are normally distributed if the significance is below 5\%, and vice versa [4].

After identifying the most proper statistical test, hyposthesis test was conducted. The test used Wilcoxon signed rank test to evaluate the results of observation prior to a treatment and after a treatment [4]. The present study involved significance rate of $5 \%$. Therefore, the alternative hypothesis $(\mathrm{Ha})$ is accepted if the prob is below the significance rate. This indicates a significant statistic difference between each financial ratio prior to and after the acquisition. The test was conducted in the following steps [13]:
1. Formulating hypothesis

2. Determining the critical area, with $\alpha=5 \%$ and $\alpha$ $=10 \%$.

3. Calculating with SPSS software

4. Comparing between the probability and the determined significance rate (5\% and 10\%)

5. Drawing statistical conclusion

- $\mathrm{Ha}$ is accepted if the Assymp Sig. value of residual data is below $\alpha=5 \%$ or 0.05 .

- $\quad \mathrm{Ha}$ is denied if the Assymp Sig. value of residual data is higher than $\alpha=5 \%$ or 0.05 .

\section{RESULTS AND DISCUSSION}

\subsection{Descriptive Statistical Analysis}

Prior to the comparative analysis of condition before and after acquisition, the results of descriptive statistical analysis for each tested financial performance are elaborated in this section. The descriptive statistical analysis result based on the secondary data is displayed as follows: 
Table 4. Hypothesis Test Results

\begin{tabular}{lcccc}
\multicolumn{1}{c}{ Ratio } & $\mathrm{Z}$ & $\begin{array}{c}\text { Assymp. Sig. (2- } \\
\text { tailed) }\end{array}$ & Std. Sig. & Description \\
\hline $\begin{array}{l}\text { CR AFTER ACQUISITION - CR } \\
\text { BEFORE ACQUISITION }\end{array}$ & $-.966^{\mathrm{b}}$ & .334 & .05 & Hypothesis is denied \\
$\begin{array}{l}\text { TATO AFTER ACQUISITION - } \\
\text { TATO BEFORE ACQUISITION }\end{array}$ & $-2.101^{\mathrm{b}}$ & .036 & .05 & Hypothesis is accepted \\
$\begin{array}{l}\text { DER AFTER ACQUISITION - DER } \\
\text { BEFORE ACQUISITION }\end{array}$ & $-.852^{\mathrm{b}}$ & .394 & .05 & Hypothesis is denied \\
$\begin{array}{l}\text { NPM AFTER ACQUISITION - } \\
\text { NPM BEFORE ACQUISITION }\end{array}$ & $-1.193^{\mathrm{b}}$ & .233 & .05 & Hypothesis is denied \\
$\begin{array}{l}\text { ROA AFTER ACQUISITION - } \\
\text { ROA BEFORE ACQUISITION }\end{array}$ & $-1.988^{\mathrm{b}}$ & .047 & .05 & Hypothesis is accepted \\
$\begin{array}{l}\text { ROE AFTER ACQUISITION - ROE } \\
\text { BEFORE ACQUISITION }\end{array}$ & $-2.613^{\mathrm{b}}$ & .009 & .05 & Hypothesis is accepted \\
$\begin{array}{l}\text { EPS AFTER ACQUISITION - EPS } \\
\text { BEFORE ACQUISITION }\end{array}$ & $-1.250^{\mathrm{b}}$ & .211 & .05 & Hypothesis is denied \\
\hline
\end{tabular}

Source: SPSS software (processed data)

\subsection{Data Normality Test Results}

Moreover, the next step is to conduct a data normality test to identify whether or not the samples involved in this study are normally distributed. Kolmogorov-Smirnov test is employed as the normality test since the data exceed the number of thirty.

The test results suggest that only one indicator that has normal distribution prior to and after acquisition, i.e., Earning per Share (EPS) with probability value of 0.200 before acquisition. In the meantime, other indicators show significance value below 0.05 , or abnormally distributed. Therefore, the study employs non-parametric Wilcoxon test to analyze the data.

\subsection{Hypothesis Test Results}

The study employs Wilcoxon signed rank test to test the hypothesis by considering that the data are abnormally distributed. Table 4 highlights the hypothesis test results.
The previous table indicates that the financial ratios that undergo significant change post-acquisition are total asset turnover, return on asset, and return on equity. On the other hand, the financial ratios as proxied by the current ratio, debt to equity ratio, net profit margin, and earning per share do not change significantly after the acquisition.

\subsection{Discussion}

\subsubsection{Difference in Liquidity Ratios Proxied with Company's Current Ratio (CR) prior to and after Acquisition}

As based on the Wilcoxon signed rank test, the variable of current ratio in the companies (that performed an acquisition in 2015) within the research time frame of three years before acquisition (2012, $2013,2014)$ and three years after acquisition (2016, 2017,2018 ) yields $\mathrm{z}$ value at -0.966 and significance rate at 0.334 . The value is larger than the determined significance rate of 0.05 . The findings suggeest no significant difference in the current ratio variable of the acquiring companies three years prior and three years after acquisition.

Current ratio (CR) is the ratio that compares between a company's current assets and short-term debt. In this regard, the current asset encompasses cash, 
account receivable, securities, inventories, and other assets.

In the meantime, short-term debt refers to the accounts payable, notes payable, bank payable, wages payable, and other payables to be paid [12]. The higher the ratio, the better the financial performance.

The acquisition is conducted with expectation to enhance the companies' financial performance. However, the research findings indicate that the companies' financial performance as represented by current ratio does not undergo significant change after the acquisition. Alternatively, the companies' acquisition does not give any significant impact to the financial performance. As based on the obtained data, the distribution of current liabilities and current assets is relatively constant, showing no significant increase or decrease in the period prior to and after the acquisition activity.

This is in line with the study conducted by [4] entitled "Analysis of Company Financial Performance Before and After Merger and Acquisition". The findings suggest no significant difference in the current ratio variable of the acquriing companies three years prior and three years after acquisition.

\subsubsection{Difference in Activity Ratios Proxied by Total Asset Turnover Ratio (TATO) Before and After Acquisition}

As based on the Wilcoxon signed rank test, the variable of total asset turnover ratio in the companies within the research time frame of three years before acquisition $(2012,2013,2014)$ and three years after acquisition $(2016,2017,2018)$ yields $z$ value at -2.101 and significance rate at 0.036 . The value is smaller than the determined significance rate of 0.05 . Thus, the findings indicate a significant difference in the total asset turnover ratio variable of the acquiring companies three years prior and three years after acquisition.

Total Assets Turnover Ratio (TATO) is the indicator of effectiveness of assets utilization in generating sales. That said, the bigger the assets turnover, the more effective the company's asset management [12]. Simply put, the extent of total asset turnover is directly proportional to the company financial performance.
Supposedly, with the acquisition, the company's assets are combined; the integrated management is also expected to be more effective and efficient. Therefore, the company's ability to manage its assets should be more optimal. However, the results depict that the total asset turnover ratio of the companies undergoes a negatively significant change. This is assumed to take place due to the company's inability to optimize the asset utilization to increase sales. That said, the acquisition process is still unable to generate the expected outcomes [8].

The findings are in line with a study conducted by [3] entitled "Comparative Analysis of Financial Performance of Acquiring Companies Adapting Public Status Before and After Acquisition in 2011-2014. The findings indicate that the total asset turnover decreases after the acquisition.

\subsubsection{Difference in Solvency Ratio Proxied by Debt to Equity Ratio (DER) Before and After}

\section{Acquisition}

The Wilcoxon signed rank test indicates that the debt to equity ratio in the companies within the research time frame of three years before acquisition $(2012,2013,2014)$ and three years after acquisition (2016, 2017, 2018) yields $\mathrm{z}$ value at -0.852 and significance rate at 0.394 , which is higher than the determined value of 0.05 . The findings show no significant difference in the ratio of the acquiring companies three years prior and three years after acquisition.

Debt to Equity Ratio (DER) is the ratio that indicates the extent to which a company owner's capital can cover the debts to other parties [14]. The higher the ratio of debt to equity, the lower the funding provided by the company's shareowners. Alternatively, a company's ability to pay its long-term obligations is better as tbe ratio decreases.

In theory, after a business merger is carried out, the company's capital will increase. Therefore, the loan capital will be smaller so as to minimize the use of debt by the company [13]. Despite this, the results show that after acquisition, the companies' debt to equity ratio is not significantly different. 
This occurs because the increase in the company's equity after making an acquisition is directly proportional to the company's debt after making the acquisition. Thus, the amount of debt used to finance the company is relatively the same, which results in the company's debt to equity being relatively constant.

The study's findings supports the research conducted by [8] entitled "Financial Performance Analysis Before and After Acquisition in NonFinancial Companies Listed in Indonesian Stock Exchange". [8] suggests that there is no significant difference in the debt to equity variable of the acquiring companies prior and after acquisition.

\subsubsection{Difference in Profitability Ratio Proxied by Net Profit Margin (NPM) Before and After Acquisition}

The variable of net profit margin in the companies (that performed an acquisition in 2015) within the research time frame of three years before acquisition $(2012,2013,2014)$ and three years after acquisition $(2016,2017,2018)$ yields $\mathrm{z}$ value at -1.193 and significance rate at 0.233 , which is higher than the significance rate of 0.05 . Therefore, there is no significant difference in the net profit margin of the acquiring companies three years prior and three years after acquisition.

Net profit margin (NPM) calculates the extent to which a company is able to generate net income at certain sales levels. The ratio is also interpreted as the company's ability to reduce costs (for efficiency measures) in a certain period [15]. The higher the ratio, the better the financial performance.

The main objective of a business merger is to implement integration/synergy in economy, technology, and managerial aspects [5]. Based on the findings, however, the acquisition does not show any hints of synergy in the companies. This menas that the companies' profits do not increase after acquisition. That said, it is assumed to take place as the company managements are still unable to optimize sales to increase profits. Such a condition indicates that the companies fail to optimize their short-term economic gains.
The study's findings are consistent with the research conducted by [1] entitled "Financial Performance Analysis in Companies Listed in Indonesian Stock Exchange Before and After Acquisition". [1] indicates that there is no significant difference in the profitability ratio as proxied by net profit margins before and after making an acquisition.

\subsubsection{Difference in Profitability Ratio Proxied by Return on Asset (ROA) Before and After Acquisition}

As based on the Wilcoxon signed rank test, the variable of return on asset in the companies (that performed an acquisition in 2015) within the research time frame of three years before acquisition (2012, $2013,2014)$ and three years after acquisition (2016, 2017,2018 ) yields $\mathrm{z}$ value at -1.988 and significance rate at 0.047 . The value is smaller than the determined significance rate of 0.05 . Thus, the findings suggest a significant difference in the return on asset of the acquiring companies three years prior and three years after acquisition.

Return on asset (ROA) shows how much net income the company accrues when measured from the value of assets [14]. The higher the ratio, the better the financial performance. An acquisition activity conducted by the company is expected to increase the return on asset. However, the results depict that the return on asset of the companies undergoes a negative change. In other words, the return on asset of the companies decreases after acquisition.

This occurs due to a decrease in post-acquisition net income which is not proportional to the company's total assets that have increased post-acquisition. This condition highlights that the company has not been able to manage its assets effectively, causing a decrease in the company's net profit.

The study's findings are consistent with the research conducted by [10] entitled "Comparative Analysis of Financial Performance in Companies Before and After Acquisition (A Study in Acquiring Companies Listed in Indonesian Stock Exchange)". [10] points out a negatively significant difference in the return on asset before and after making an acquisition. 


\subsubsection{Difference in Profitability Ratio Proxied by Return On Equity (ROE) Before and After Acquisition}

As based on the Wilcoxon test, the variable of return on equity in the companies within the research time frame of three years before acquisition (2012, $2013,2014)$ and three years after acquisition (2016, 2017,2018 ) yields $\mathrm{z}$ value at -2.613 and significance rate at 0.009 . The value is smaller than the determined significance rate of 0.05 . In other words, there is a significant difference in the return on equity of the acquiring companies three years prior and three years after acquisition.

Return on equity (ROE) is used to measure a company's ability to generate net profit based on particular capital [15]. The higher the ratio, the better the financial performance, and vice versa.

An acquisition activity conducted by the company is expected to increase the return on equity. However, the results suggest otherwise; the companies' return on equity undergoes a negative change and decreases after acquisition.

This occurs due to a decrease in post-acquisition net profit which is not proportional to the company's total equity that has increased post-acquisition. The decline indicates that the company has not been able to effectively manage its own capital from the investments that have been made by the owners of capital, causing a decrease in the company's net profit.

The findings are not in line with a study conducted by [3] entitled "Comparative Analysis of Financial Performance of Acquiring Companies Adapting Public Status Before and After Acquisition in 2011-2014". The results indicate that the companies' ROE decreases after acquisition.

\subsubsection{Difference in Market Ratio Proxied by} Earnings per Share (EPS) Before and After Acquisition

As based on the Wilcoxon signed rank test, the variable of earning per share in the companies (that performed an acquisition in 2015) within the research time frame of three years before acquisition (2012, $2013,2014)$ and three years after acquisition (2016,
$2017,2018)$ yields $\mathrm{z}$ value at -1.250 and significance rate at 0.211 . The value is larger than the determined significance rate of 0.05 . That said, there is no significant difference in the earning per share three years prior and three years after acquisition.

Earnings Per Share (EPS) is the indicator of company's ability to generate profits per share of the owner [12]. The higher the ratio, the better the financial performance. A company makes an acquisition to increase the financial performance, as the representation of the company's financial condition in a particular period. That said, it is the measure of company achievement. A company is able to gain investors if the financial performance is good [3].

The earning per share as the market ratio is a significant variable to the investors. The higher the company earning per share, the better the profit the company gains from the investment. Based on the findings, however, the acquisition does not show significant change in earning per share. This condition highlights that the company has not been able to increase net profit post-acquisition.

The findings are consistent with a study conducted by [19] entitled "Difference in Financial Performance in Companies Listed in the Indonesian Stock Exchange Before and After Acquisition". [19]'s results indicate no significant difference in earning per share before and after acquisition.

Signal theory explains a sign given by management to parties who have an interest in the company about how management sees the company's prospects in the future [9]. The signals can take the form of information stating whether or not the company's financial condition is in healthy condition as reflected from the financial report. The study results provide signs to the related authorities of the companies whether or not the acquisition generates good or bad results to the financial performance.

\section{CONCLUSIONS}

\subsection{Conclusions}

As based on the research findings, the study concludes that: 
1. There is no significant difference in the company financial performance before and after acquisition as based on the Current Ratio (CR).

2. There is a significant difference in the company financial performance before and after acquisition as based on the Total Asset Turnover Ratio (TATO).

3. There is no significant difference in the company financial performance before and after acquisition as based on the Debt to Equity Ratio (DER).

4. There is no significant difference in the company financial performance before and after acquisition as based on the Net Profit Margin (NPM).

5. There is a significant difference in the company financial performance before and after acquisition as based on the Return On Assets (ROA).

6. There is a significant difference in the company financial performance before and after acquisition as based on the Return On Equity (ROE).

7. There is no significant difference in the company financial performance before and after acquisition as based on the Earning Per Share (EPS).

As based on the previous findings, the study concludes that acquisition yields negative impacts to the company financial performance. As based on the findings, four of seven financial ratios (CR, DER, NPM, and EPS) do not have significant change, while three ratios (TATO, ROA, and ROE) undergo negatively significant change post-acquisition.

\subsection{Recommendations}

As based on the research findings and conclusions, the study formulates several recommendations as follows:

\subsubsection{To the company}

As based on the findings, it is given that the TATO, ROA, and ROE undergo negatively significant change post acquisition, while the other ratios do not change significantly. This suggests that the company must be wary in deciding to make an acquisition, as the study shows that acquisition does not always generate better financial performance.

\subsubsection{To the investors}

The research findings indicate that the earning per share ratio does not change in a significant way. This ratio is significant for investors; it is important for investors to be aware that acquisition does not always result positively on the company efficiency.

\subsubsection{For further studies}

The research findings indicate several ratios that does not show significant change. The study calls for further research on the aforementioned ratios by involving other factors to investigate the impact of acquisition to the company financial performance.

\section{AUTHORS' CONTRIBUTIONS}

In this study, the first author contributes to collect the data, while the second author contributes to plan and design the research, and the third author acts to process and analyze the data.

\section{ACKNOWLEDGMENT}

The authors would like to express their gratitude to all parties whose contributions to this study has been significant, particularly to the management of investment gallery of Universitas Negeri Gorontalo that has facilitated the data collection process.

\section{REFERENCES}

[1] Indriani, Ayu Nur. 2018. Analisis Kinerja Keuangan Perusahaan Yang Terdaftar Di Bursa Efek Indonesia (BEI) Sebelum Dan Sesudah Akuisisi. Jurnal Ilmu Manajemen Vol. 15 No. 1.

[2] Esterlina, Prisya dan Nila Nuzula Firdausi. 2017. Analisis Kinerja Keuangan Perusahaan Sebelum Dan Sesudah Merger Dan Akuisisi. Jurnal Administrasi Bisnis (JAB) Vol. 47 No. 2. Universitas Brawijaya.

[3] Erlyene, Putrid dan Musdholifah. 2019. Analisis Komparatif Kinerja Keuangan Perusahaan Akuisitor Sebelum Dan Sesudah Akuisisi Yang Go Publik Antara 2011-2014. Jurnal Ilmu Manajemen Vol. 7 No. 3 Fakultas Ekonomi Universitas Negeri Surabaya.

[4] Finansia, Linda. 2017. Analisis Kinerja Keuangan Perusahaan Sebelum Dan Setelah Merger Dan Akuisisi. Skripsi. Fakultas Ekonomi Universitas Negeri Yogyakarta.

[5] Octaviani, Maeninta. 2018. Perbandingan Kinerja Keuangan PerusahaanSebelum Dan Sesudah Melakukan Aktivitas Merger Dan Akuisisi. 
Buletin Ekonomi Vol. 22 No. 12018. ISSN: 14103842

[6] Naziah, Ulfathin. Yusralaini., dan Al Azhar L. 2014. Analisis Perbandingan Kinerja Keuangan Perusahaan Sebelum Dan Sesudah Merger dan Akuisisi Pada Perusahaan Manufaktur Yang Listing Di BEI 2009-2012. Jom Fekon Vol. 1 No. 2.

[7] Juaneschar, Ahsan. 2018. Analisis Pengaruh Merger dan Akuisisi Terhadap Kinerja Keuangan Perusahaan (Pada Perusahaan Pengakuisisi Di Indonesia YangTerdaftar Di BEI Dengan Periode Merger Dan Akuisisi 20132014). Skripsi. Fakultas Ekonomika dan Bisnis Universitas Diponegoro.

[8] Hanantyo, Philliphus Ergi. 2017. Analisis Kinerja Keuangan Sebelum Dan Sesudah Akuisisi PadaPerusahaan Non-Keuangan Yang Terdaftar Di Bursa Efek Indonesia (BEI). Skripsi. Fakultas Ekonomi Universitas Negeri Yogyakarta.

[9] Septiawan. I Putu Doni Aditya dan Ni Ketut Rasmini. 2018. Analisis Perbandingan Kinerja Keuangan Perusahaan Sebelum Dan Sesudah Merger Dan Akuisisi Periode 2011-2014. EJurnal Akuntansi Vol.24. No. 1 Hal: 687714ISSN: 2302-8556. Universitas Udayana.

[10] Serenade, Vincensia. 2018. Analisis Perbandingan Kinerja Keuangan Perusahaan Sebelum Dan Sesudah Akuisisi Studi Pada Perusahaan Pengakuisisi Yang Terdaftar Di Bursa Efek Indonesia. Skripsi. Fakultas Ekonomi Universitas Sanata Dharma Yogyajakrta.

[11] Fahmi, Irham. 2012. Pengantar Manajemen Keuangan (Teori dan Soal Jawab). Bandung: Alfabeta.

[12] Sutrisno. 2012. Manajemen Keuangan Teori Konsep dan Aplikasi. Yogyakarta: Ekonisia

[13] Indriani, Ayu Nur. 2017. Analisis Kinerja Keuangan Perusahaan YangTerdaftar Di Bursa Efek Indonesia (BEI) Sebelum Dan Sesudah Akuisisi. Skripsi. Fakultas Ekonomi Universitas Negeri Yogyakarta.

[14] Harahap, Sofyan Syafri. 2013. Analisis Kritis Atas Laporan Keuangan. Jakarta: PT Rajagrafindo Persada
[15] Hanafi, Mahmud M. 2015. Manajemen Keuangan. Yogyakarta: BPFE

[16] Fahmi, Irham. 2016. Pengantar Manajemen Keuangan (Teori dan Soal Jawab). Bandung: Alfabeta.

[17] Laiman, Lisa dan Saarce Elsye Hatane. 2017. Analisis Dampak Merger Dan Akuisisi Terhadap Kinerja Keuangan Pada Perusahaan Non Keuangan Yang Terdaftar Di Bursa Efek Indonesia Periode Tahun 2007 - 2014. Accounting Review Vol. 5 No. 2 Hal: 517-528. Akuntansi Bisnis Universitas Kristen Petra.

[18] Febrina, Rezmia. 2014. Proses Akuisisi Perusahaan Berdasarkan Undang-Undang No 40 Tahun 2007 Tentang Perseroan Terbatas. Jurnal Ilmu Hukum. Vol. 4 No. 1.

[19] Rahmawati, Sinta Rahayu dan Diah Lestari Mumpuni. 2018. Perbedaan Kinerja Keuangan Sebelum Dengan Sesudah Akuisisi Terhadap Perusahaan Yang Terdaftar Di BEI. Jurnal Manajemen Dewantara Vol 2 No 2 Hal: 122 127. Universitas Sarjanawiyata Tamansiswa.

[20] www.kppu.go.id diakses tanggal 7 November 2019. 